\title{
CONCEPTUAL DESIGN OF URBAN E-BUS SYSTEMS WITH SPECIAL FOCUS ON BATTERY TECHNOLOGY
}

\author{
Göhlich, Dietmar (1); Fay, Tu-Anh (1); Park, Sangyoung (2)
}

1: Department of Methods for Product Development and Mechatronics Technische Universität Berlin;

2: Department of Smart Mobility Systems Technische Universität Berlin

\begin{abstract}
Many cities have announced ambitious plans to introduce zero-emission electric bus systems. The transformation process to electric bus systems opens up a vast design space as different charging strategies, charging technologies and battery types are available. Therefore, a profound assessment strategy is necessary to find a "most suitable system solution" under given strategic and operational requirements.

In this study, we present a new methodology for conceptual design of urban electric bus systems. First, the available e-bus technologies are analysed with a special focus on charging systems, battery technology and aging. Relational functional analysis is used to derive a suitable simulation model. Based on the operational requirements, an energetic simulation of the e-bus is carried out, and the required battery capacity is obtained. Subsequently, the design space is reduced by applying a qualitative costtechnology compatibility matrix taking cost and battery aging into account. The applicability of the model is shown for an exemplary realistic operational scenario to identify three most expedient concepts, which are finally validated with an in-depth analysis.
\end{abstract}

Keywords: Conceptual design, Design methodology, Sustainability, Urban electric bus systems, Battery and charging technologies

\section{Contact:}

Park, Sangyoung

Technical University of Beril;n

Smart Mobility Systems

Germany

sangyoung.park@tu-berlin.de

Cite this article: Göhlich, D., Fay, T.-A., Park, S. (2019) 'Conceptual Design of Urban E-Bus Systems with Special Focus on Battery Technology', in Proceedings of the 22nd International Conference on Engineering Design (ICED19), Delft, The Netherlands, 5-8 August 2019. DOI:10.1017/dsi.2019.289 


\section{INTRODUCTION, RELATED WORK AND METHODOLOGY}

Many metropolitan areas are targeting zero-emission environments, and increasing number of cities and transport companies have a great interest in introducing zero-emission buses. However, replacing today's fleets of diesel buses with electric vehicles requires a complete system change with a rather complex technology assessment.

Contrary to diesel buses, whose range and infrastructure requirements are comparable among options available industry-wide, electric buses can be operated using different charging strategies (Göhlich et al., 2018):

- Depot charging (DC): The battery is only charged during the operating pause in the depot, usually with a manual plug. The maximum range of such buses is currently about 200 to $300 \mathrm{~km}$. Depot charging is also known as overnight or slow charging.

- Opportunity charging (OC), also referred to as fast charging: The batteries are charged several times during operation, usually during dwell times at terminal stations, by automated charging systems. The daily range is therefore theoretically unlimited and is only limited by cleaning and maintenance procedures in the depot. Since only short dwell times are available, high charging power is required. Alternatively, a battery swapping system can be set-up where batteries are changed rapidly and recharged slowly.

- In motion charging is derivative of the well-known trolley bus system. The roadway of the buses is partially equipped with an overhead cable, which is connected with the vehicle by means of a current collector. The batteries are charged while driving under the overhead cable, so that the energy for route segments without overhead wires can be supplied by the battery storage. In motion charging is also possible using inductive systems. The daily range is also theoretically unlimited.

Hence three charging strategies can be combined with different charging interfaces. Additionally, different battery technologies are available. Considering the three most widely used battery types, this leads to a morphological matrix with 45 different system solutions which are theoretically possible as shown in Figure 1. A complete evaluation of this design space is prohibitive. Additionally, the determination of charging power and battery capacity adds further variables to this complex technology selection problem. Therefore, a profound assessment strategy is necessary to find a "most suitable system solution" under given strategic and operational requirements. ${ }^{1}$

\begin{tabular}{|c|c|c|c|c|c|}
\hline Function & \multicolumn{5}{|c|}{ Options } \\
\hline $\begin{array}{l}\text { Charging } \\
\text { Strategy }\end{array}$ & $\underset{\text { depot }}{\mid}$ & opportunity & in motion & & \\
\hline $\begin{array}{c}\text { Charging } \\
\text { System }\end{array}$ & $\begin{array}{l}\text { manual } \\
\text { (plug, pump nozzle) }\end{array}$ & induction & $\mid \sum_{\text {pantograph }}^{2}$ & $\begin{array}{c}\text { trolleybus current } \\
\text { collector }\end{array}$ & battery swapping \\
\hline \multirow[t]{2}{*}{$\begin{array}{l}\text { Battery } \\
\text { System }\end{array}$} & \multicolumn{3}{|c|}{$\underset{\text { battery }}{-+\boldsymbol{T}}$} & & \\
\hline & LFP & NMC & LTO & & \\
\hline
\end{tabular}

Figure 1: Morphological matrix of available technology options in electric bus systems

Different aspects of this technology transformation and the related capital and operational cost have been covered in numerous papers. Rogge et al. (2015) and Sinhuber et al. (2012) used a simulation model to determine the route specific energy consumption and calculate the required battery size. Rogge et al. (2015) further discussed the trade-off between passenger and battery capacity and the interdependency between charging power and battery capacity in order to electrify an existing bus network. Battery sizing is investigated in Gao et al. (2017).

\footnotetext{
${ }^{1}$ Fuel cell powered busses are not considered in this study because the cost of the required infrastructure and the current market price of hydrogen is not yet competitive.
} 
However, the battery cost has not been considered to the full extent so far. Despite recent advances in material and manufacturing processes of Li-ion batteries, the battery persists to be the limiting factor in terms of drive range and lifespan of the vehicle. A recent work, Göhlich et al. (2018), identified three most competitive Li-ion battery chemistries and corresponding charging strategies, lithium iron phosphate (LFP), lithium titanium oxide (LTO) and lithium nickel manganese cobalt oxide (NMC) for E-bus systems and performed a total cost of ownership (TCO) analysis. While the work provides a holistic and thorough cost analysis, rather simplistic battery aging models have been used and therefore, their lifespans have been conservatively estimated. For electric urban busses it is still common practice to assume a battery life of up to 6 years (Rogge and Sauer, 2013, Bünnagel 2016, Eudy et al., 2016, Nørregaard et al., 2016), regardless of the specific battery type and the operational characteristics. However, it has been shown that proper considerations of the battery aging patterns could be accurate to assess the battery related costs (Park et al., 2017).

In this paper, we propose a design methodology to effectively reduce the design space and identify the most feasible design concepts taking the aging rates of different battery types into account.

\section{METHODOLOGY}

Due to the large number of possible solutions a comprehensive quantitative analysis of the complete design space is prohibitive. In this paper we propose a systematic approach to identify a subset of "most promising" system solutions as shown in Figure 2.

In the first step an analysis of the available e-bus technologies with a special focus on charging systems, battery technology and aging is conducted (see Section 3). Together with the operational requirements (see Section 4) an energetic simulation of the e-bus (Section 5) can be carried out and on this basis the required battery capacity is obtained. Subsequently the design space can be reduced by applying a qualitative cost-technology compatibility matrix which takes cost and battery aging into account. The most expedient concepts can be analysed in detail and finally validated.

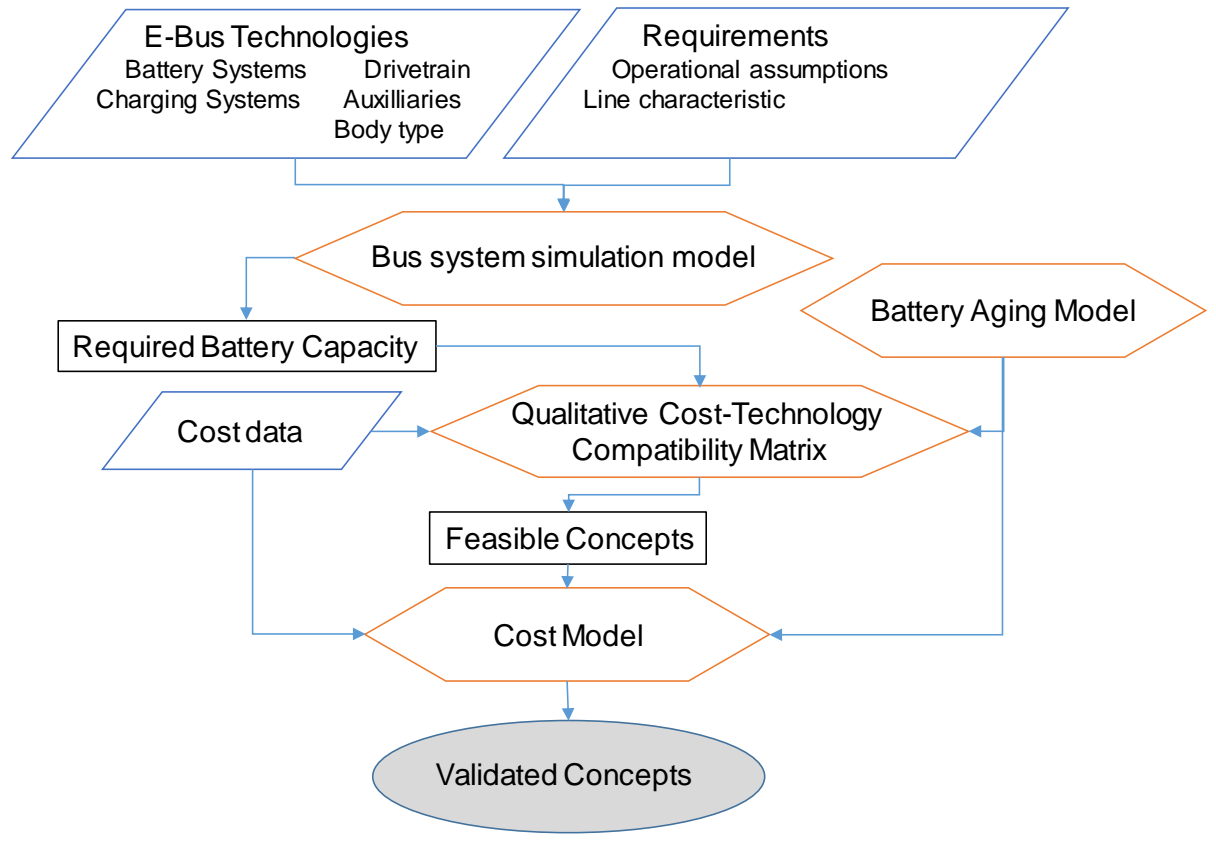

Figure 2: Holistic design methodology for electric bus technologies

\section{URBAN ELECTRIC BUS TECHNOLOGIES}

In this section, we will give an overview to battery and charging systems and discuss the technical parameters most important for electric bus system design. For a discussion of other relevant components like body, drivetrain and auxiliaries and their influence on electric bus system design we refer to Göhlich et al. (2018). 


\subsection{Battery system}

Recent advances in battery technology and the drive down in pack cost have boosted the usage of battery systems in electric vehicles. In the past, various battery chemistries have been considered, ranging from non-lithium-based batteries such as Nickel-Metal hydride (NiMH) batteries used in Toyota Prius hybrid electric vehicles to various lithium-based batteries such as Lithium Nickel Cobalt Aluminium Oxide (NCA) for Tesla Model S, Lithium Iron Phosphate (LFP) batteries for BYD electric buses, Lithium Titanate (LTO) batteries for Proterra Electric Buses, Lithium manganese oxide (LMO) for Nissan Leaf, Chevy Volt and BMW i3, and finally Lithium Nickel Manganese cobalt oxide (NMC) batteries. Among these, LFP, LTO and NMC batteries are the most suitable cell types used in electric buses (Göhlich et al., 2018).

Li-ion cells of different chemistries exhibit distinct characteristics in terms of cell voltage, energy density, maximum charging rate, and cycle life as shown in Table 1. NMC cells are superior in terms of energy density, while LTO cells are superior in terms of cycle life and allow high charging rates. The LFP lies somewhere in between and has an advantage in terms of cost, but suffers from limited charging power expressed by the charge rate (C-rate).

Table 1: Characteristics for different Lithium-based battery technologies

\begin{tabular}{|l|c|c|c|c|}
\hline & & LFP & LTO & NMC \\
\hline Cell voltage & $\mathrm{V}$ & $\approx 3.2$ & $\approx 2.3$ & $\approx 3.6$ \\
\hline Cell capacity & $\mathrm{Ah}$ & $14 \ldots 45$ & $20 \ldots 65$ & $37 \ldots 53$ \\
\hline Energy density (gravimetric) & $\mathrm{Wh} / \mathrm{kg}$ & $115 \ldots 146$ & $76 \ldots 77$ & $165 \ldots 175$ \\
\hline Charge rate (C-rate), continuous & & $1 \mathrm{C}$ & $4 \mathrm{C} \ldots 10 \mathrm{C}$ & $2 \mathrm{C} \ldots 3 \mathrm{C}$ \\
\hline Cycle life (at 100\% DoD) & & 3000 & $10,000 \ldots 20,000$ & $1000 \ldots 5000$ \\
\hline
\end{tabular}

Another major aspect, besides battery capacity and charging power, is the longevity of the battery. Battery degradation is usually depicted in terms of state-of-health ( $\mathrm{SOH})$, which involves mainly decrease in battery capacity, and increased internal resistance, making the battery unsuitable for E-bus applications after repeated charge/discharge cycles. In case of Li-ion batteries with graphite anodes, volume changes of the electrode during charge/discharge cycles lead to crack in solid electrolyte interface (SEI) films, allowing contact between the graphite and the electrolyte solution, which results in gradual loss of lithium inventory (Aurbach 2000). LTO battery cells are more resilient to this effect because they do not have a SEI film and volumetric changes in the electrodes are minimal.

A number of factors affect the aging rate of the batteries. Cathode and anode materials, and battery working conditions such as the temperature, cell current, and depth-of-discharge (DoD). A number of models, which take into account the average SoC (state of charge), SoC deviation, and temperature (Millner 2010), as well as the C-rate (Suri, 2016) have been proposed. In the analysis of this paper, we make use of the model from Millner (2010) for LFP cells and fitted parameters to model the LTO and NMC batteries where resulting the cycle life is shown in Figure 3. The measurement data used for fitting is obtained from Koebel (2014).

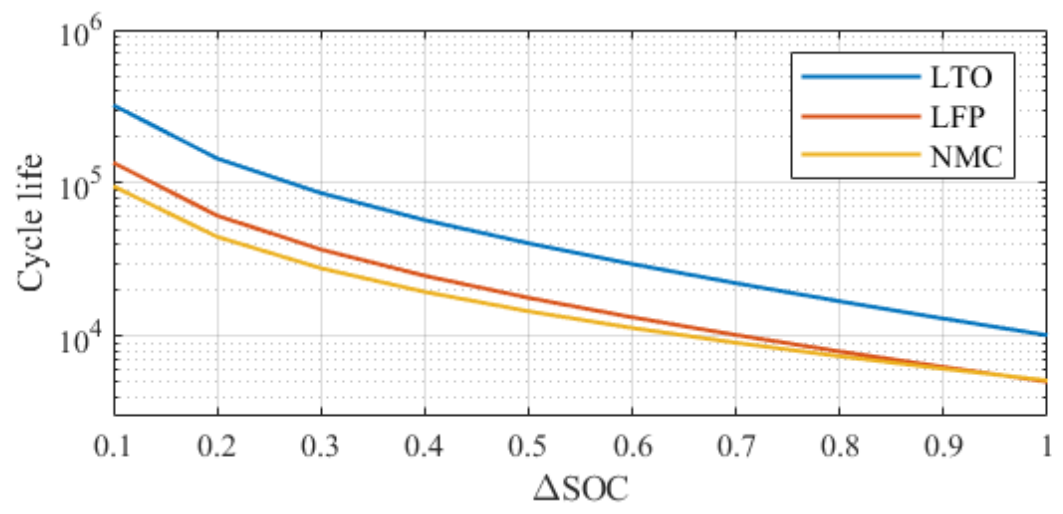

Figure 3: Cycle life of LTO, LFP, and NMC batteries fitted into aging model from Millner (2010) 


\subsection{Charging systems}

The charging system is another essential component in e-bus conceptual design. The long charging time persists to be one of the major hurdles in operating an e-bus. A number of options have been considered in this paper, which is also shown in Figure 1. The concepts are distinguished in terms of charging interface i.e., i) manual plug-in of nozzles, ii) inductive charging without physical contacts, iii) conductive charging using pantograph, iv) trolley bus current collector, and v) and battery swapping.

In this paper, we consider three technology options i), ii) and iii), which are less rigid than iv), and more readily available at hand in contrast to prospective technologies such as v). Based on these arguments, battery swapping and trolley bus current collector are not considered as feasible concepts within in the framework of this study.

Regarding manual charging, manual plug interface (CCS, combined charging system) is the most common option in European vehicles. In case of fast charging, thermal management capabilities are integrated to the standard. Inductive systems require a coil beneath the road surface and a matching coil on the vehicle side for wireless energy transfer. An example is a system with a fixed or shifting vehicle-side coil (Bombardier Transportation 2015). Various options for conductive charging exists including pantographs mounted on the roof of a vehicle or on a wayside pole. Often these options are incompatible and non-interoperable, and the EU is putting an effort in developing a European standard for conductive charging interfaces by the end of 2019 and for inductive charging interfaces by the end of 2018 (European Commission 2015).

The charging concepts are also distinguished by charging strategies as discussed in the introduction. But not all battery types are compatible with each charging strategies. As opportunity charging strategies make use of the short dwell times of e-busses at terminal stations, battery types with limited charging capacity such as LFP are not conducive to such strategies. LFP goes along better with depotcharging strategies as it requires larger capacity and hence, cheap unit price benefits. Such characteristics are considered in the methodology proposed in the subsequent chapters.

\section{OPERATIONAL REQUIREMENTS AND COST DATA}

The conceptual design of an electric bus system has to take the relevant requirements into account. Most important are the daily operation range, distance of trips, driving pattern and idle time at end stops. Contrary to diesel buses, where vehicle range is rarely a problem, the deployment of electric buses may be limited depending on the battery and charging technology used.

The energy consumption is largely influenced by the driving pattern. Various synthetic and measured diving cycles are available in the literature and the presented approach is not limited to a particular driving pattern. In this study we assume an inner city bus line with a flat topology. In particular, the so called "Manhattan Cycle" with an overall length of $6.65 \mathrm{~km}$ and a dwell time of $10 \mathrm{~min}$. is used here.

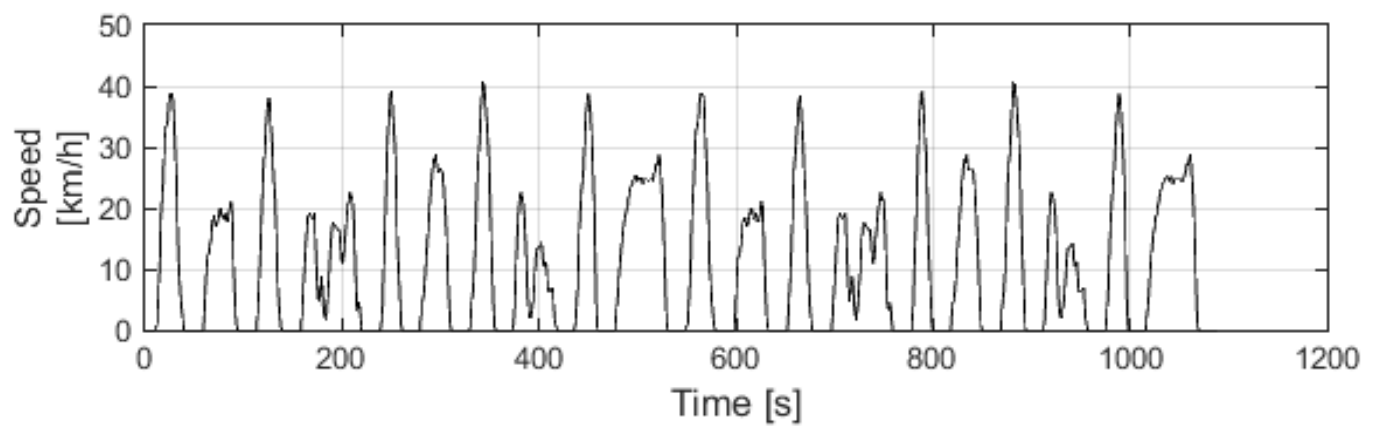

Figure 4: Speed profile of Manhattan Bus Cycle (two times)

Exemplarily, a $12 \mathrm{~m}$ single-deck bus with a passenger occupancy of $20 \%$ and average auxiliary power of $8 \mathrm{~kW}$ is considered.

Conceptual system assessment has to take technological factors and operational requirements, as well as economic aspects into account. Cost data for the economical assessment has been derived from extensive literature review and interviews with experts from European manufacturers (Fay 2019). Here only the cost data for different battery technologies are compiled, which are used in the subsequent system evaluation. 
Table 2: Cost data for battery procurement in 2017 based on Fay (2019)

\begin{tabular}{|l|l|l|l|}
\hline Cost data / Battery technology & LTO & NMC & LFP \\
\hline Battery storage system $(€ / \mathrm{kWh})$ & 950 & 800 & 430 \\
\hline
\end{tabular}

\section{INTERDEPENDENCIES AND SIMULATION MODEL}

An evaluation of competing system technologies should be based on an analysis of well-defined performance and cost metrics. Urban electric bus system can be described by several performance indicators like the energy consumption per trip or the possible range per charge. System cost depends on initial and operational cost, both can vary substantially between variants as described above.

From an operator's point of view, a system decision can be based primarily on the assessment of total cost of ownership (TCO) as the crucial key performance indicator as shown in Spangenberg and Göhlich (2013) The forecast of TCO for different technological systems, however, requires a thorough understanding of the overall system and the interdependencies of the subsystems.

Here, the method of relation-oriented function modelling is applied. Due to the high complexity of the system, the representation is done in a network-like structure as proposed by Lindemann (2009). Performance indicators and dependencies are derived from the interactions between relational and property characteristics (see Fay (2019)) as shown in Figure 5. All relevant system functions can be related to system TCO, which is commonly used as a key performance indicator in technology assessment.

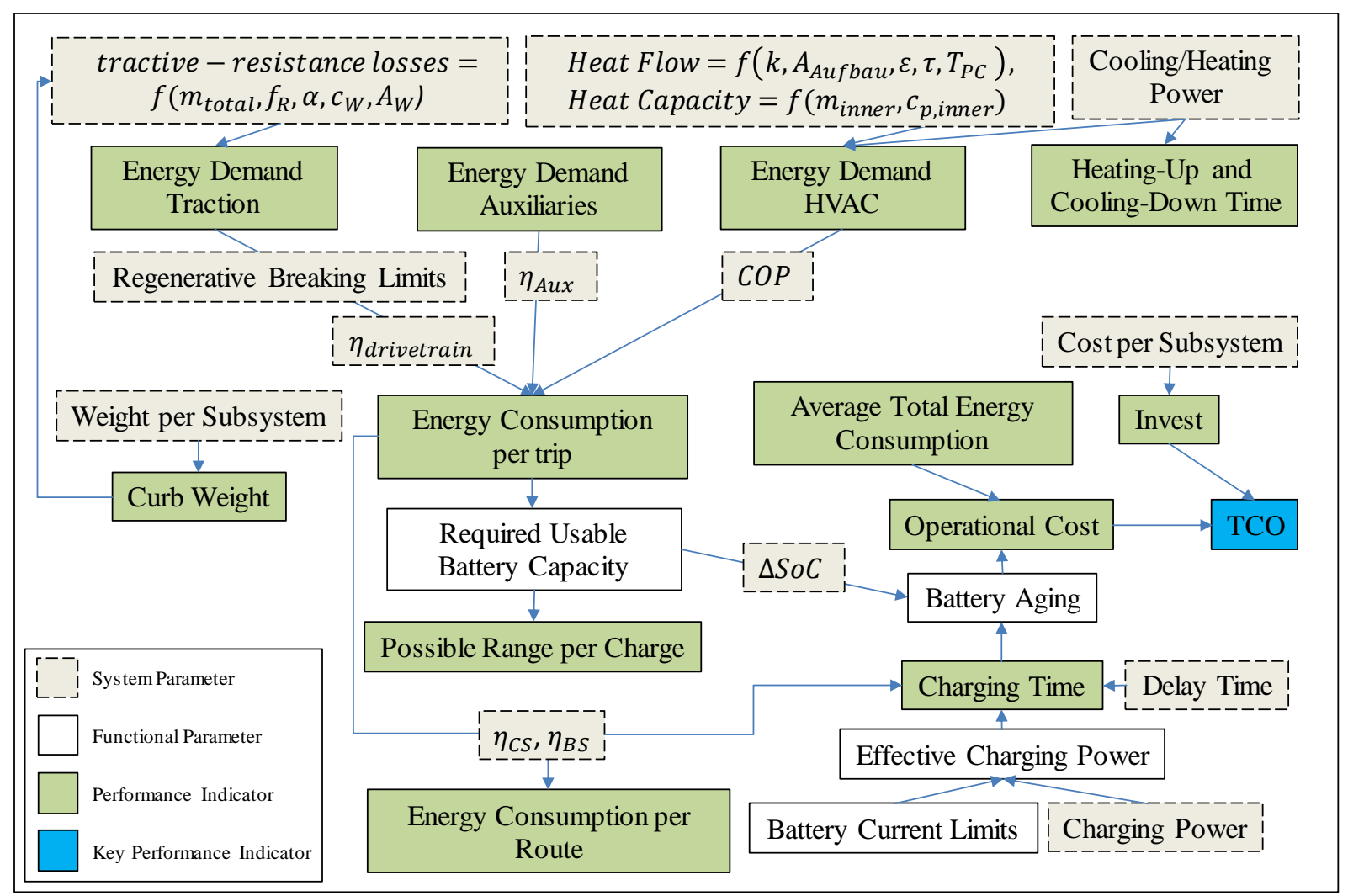

Figure 5: Interdependencies between System Parameters and Performance Indicators

In order to reduce the vast design space, we use a compatibility matrix. Hellenberg et al. (2008) introduced the compatibility design structure matrix used to identify partial design solutions that can be combined to create a set of "valid" overall concept combinations of partial solutions. This idea has been further developed by Gorbea et al. (2010) and renamed to compatibility matrix because this matrix is not used to cluster or analyse feedback loops as usually proposed in design structure matrix literature. With the compatibility matrix a set of consistent concepts will be chosen and further considered. A modular bus system simulation model has been developed and verified in a pilot project in Berlin as shown in in Ly et al. (2016) which takes all relevant system and functional parameters into account. Here the model is used to determine relevant design parameters such as battery capacity, 
SoC range, and charging time. With these parameters the battery aging can be incorporated into the model based on the aging model described in Section 3.1.

\section{METHODOLOGY APPLICATION}

In this chapter the methodology described above is applied to obtain a selection of feasible and cost effective e-bus system concepts.

\subsection{Identification of feasible concepts}

From the large design space, a small number of feasible concepts are identified using a two-step approach.

Firstly, we analyse the possible combinations of charging strategy, systems and technologically available charging power. Charging the buses in the depot opens a fairly large time window (typically overnight), hence slow charging of approx. $100 \mathrm{~kW}$ with lower invest than fast charging is chosen, here. For opportunity charging the currently available technologies have been analysed. Inductive charging has been proven with pilot applications up to $200 \mathrm{~kW}$ but not beyond, conductive charging using pantograph systems are running reliably with substantially higher charging power. This evidence is independent from the operational scheme. Hence, as a general guideline, three meaningful combinations of charging strategy, charging systems and technologically available charging power could be identified as shown in the left column of Figure 6.

\begin{tabular}{|c|c|c|c|c|}
\hline Battery System & LFP & NMC & LTO & \\
\hline & + & - & - & System Cost \\
\hline & + & + & + & techn. compatible \\
\hline & + & + & - & System Cost \\
\hline $\begin{array}{l}\approx 200 \mathrm{~kW} \\
\text { retunity Inauction }\end{array}$ & - & + & + & techn. compatible \\
\hline & + & + & + & System Cost \\
\hline$>200 \mathrm{~kW}$ & - & - & + & techn. compatible \\
\hline
\end{tabular}

Figure 6: Compatibility Matrix

Secondly a suitable battery system has to be identified from the remaining 9 possible combinations which are evaluated based on compatibility matrix (Gorbea et al., 2010). Here we have adapted this approach using a qualitative cost-technology compatibility matrix as shown in Figure 6. There are two aspects we consider during this process, i) system cost and ii) technological compatibility. In order to evaluate the two aspects it is essential that the characteristics of batteries given in Table 1 and Figure 3 are considered.

The system cost comprises procurement costs of the vehicle where the initial battery cost and depreciation costs play important roles. The initial battery cost is related to the required battery capacity, which we determine from the energetic simulation model described above. For the considered bus line, operational scheme leads to a required battery capacity of $324 \mathrm{kWh}$ when charging in the depot, only. This is substantially more than in the case of opportunity charging, where only $83 \mathrm{kWh}$ for conductive pantograph or $90 \mathrm{kWh}$ using inductive charging are required. As shown in Table 1, NMC has a gravimetric advantage, however, the significantly lower unit cost of LFP (as shown in Table 2) makes it more suitable for depot charging. Since inductive charging is currently limited to $200 \mathrm{~kW}$, in this case both NMC and LTO batteries with more than $2 \mathrm{C}$ are technologically applicable. Due to the cost advantage NMC can be identified as the best choice. For charging power above $200 \mathrm{~kW}$ and high charge rate, LTO battery systems were selected. The relatively high unit cost is accepted due to their superior resilience to high current as indicated by the C-rate in Table 1. 
Eventually three feasible concepts, shown in Table 3, could be identified, opportunity charging via inductive interface with a NMC battery pack (OC 1), opportunity charging using a pantograph with a LTO battery pack (OC 2), and depot charging using manual plug interface with an LFP battery pack.

Table 3: Feasible Concepts

\begin{tabular}{|l|l|l|l|l|l|l|}
\hline Case & $\begin{array}{l}\text { Charging } \\
\text { strategy }\end{array}$ & $\begin{array}{l}\text { Charging } \\
\text { interface }\end{array}$ & $\begin{array}{l}\text { Maximum } \\
\text { charging power }\end{array}$ & $\begin{array}{l}\text { Battery } \\
\text { type }\end{array}$ & $\begin{array}{l}\text { Charging } \\
\text { rate }\end{array}$ & $\begin{array}{l}\text { Battery } \\
\text { size }\end{array}$ \\
\hline OC 1 & Opportunity & Induction & $200 \mathrm{~kW}$ & NMC & $3 \mathrm{C}$ & $90 \mathrm{kWh}$ \\
\hline OC 2 & Opportunity & Pantograph & $375 \mathrm{~kW}$ & LTO & $4 \mathrm{C}$ & $83 \mathrm{kWh}$ \\
\hline DC & Depot & Plug & $75 \mathrm{~kW}$ & LFP & $1 \mathrm{C}$ & $324 \mathrm{kWh}$ \\
\hline
\end{tabular}

\subsection{Concept validation and evaluation}

The three feasible concepts are finally evaluated in detail with special focus on battery technology and the cost. Initial invest and resilience to aging is taken into account. For an in-depth comparison of the technologies for e-bus applications, the parameters in

Table 3 are obtained from the following assumptions. We assume a setup from Göhlich et al. (2018), a 12-meter bus capable of supporting a maximum passenger density of 4 people $/ \mathrm{m}^{2}$, which leaves approximately $3400 \mathrm{~kg}$ for the battery system. However, not all could be allocated to the cells and the presence of electronics and cooling equipment reduces the effective energy density of the whole battery systems roughly by a factor of 0.6 . This determines the upper limit of the battery weight, which is the case in the DC concept.

However, OC 1 and OC 2 do not require such a large battery as it becomes an unnecessary payload to carry. For OC 1 and OC 2, we determine the size of the batteries such that the SoC window swings between $30-70 \%$ in case of worst case usage scenarios depicted in Göhlich et al. (2018). This is to limit high-cycle fatigue of the battery. The specific layout of the battery system (number of cells in series and parallel) differs slightly resulting in the difference in capacity between OC 1 and OC 2 . Maximum charging power is subject to the maximum C-rate of the battery technology, e.g., the charging power of $375 \mathrm{~kW}$ cannot be used with the NMC battery pack. The resulting battery charging power and capacity configurations are illustrated in Figure 7. Further parameters for batteries and charging systems required for the simulation are summarized in Ly et al. (2016). The final evaluation is carried out for a real world drive cycle described in Section 4.1 based on our simulation model.

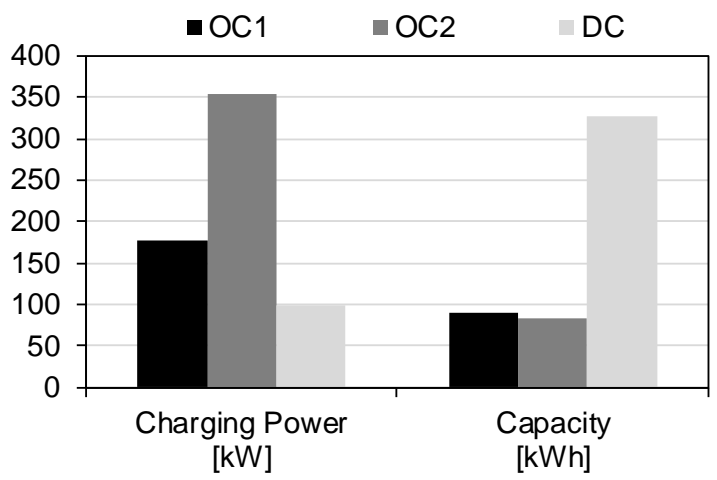

Figure 7: Battery capacity and charging Power of the different bus system designs for OC

Figure 8 shows distinct patterns in change of SoC over time for different scenarios. For scenarios OC 1 and OC 2, the battery is charged much more frequently and the deviation of SoC is much smaller. OC is enabled by faster charging speeds of LTO and NMC batteries compared to LFP batteries. For the DC scenario, deviation in SoC is much higher as it is being charged only at night at a much lower C-rate. 

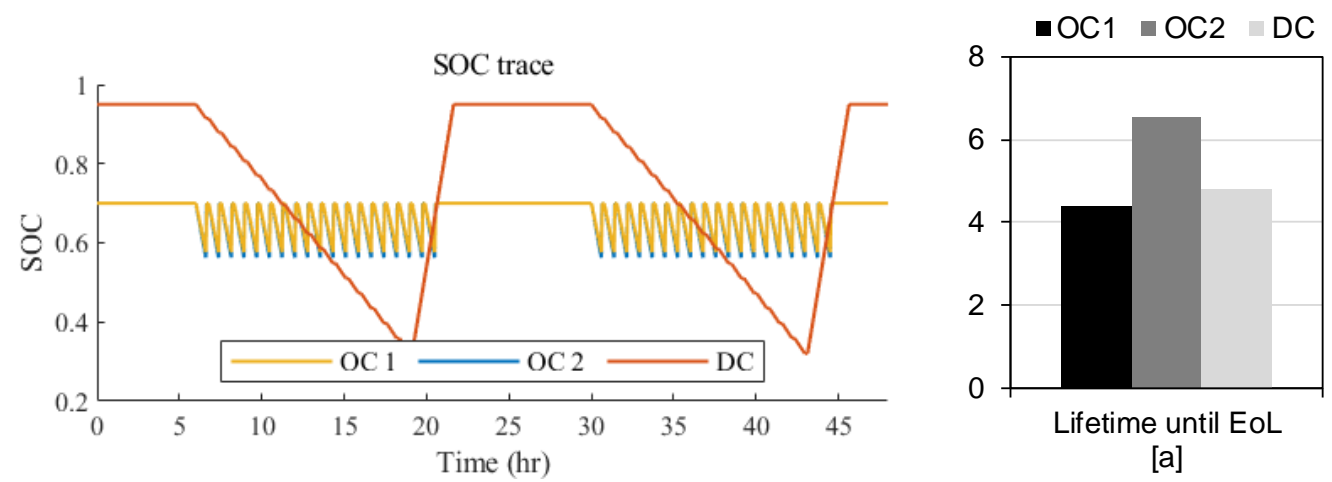

Figure 8 SoC patterns of batteries over time according to different charging scenarios (left), Battery life time until EOL for three scenarios (right)

Our analysis shows the superior life time of LTO batteries for OC2 scenario (over 6 years), while OC 1 and DC, although they experience completely different charging patterns, exhibit shorter but similar battery life times. OC 2 exhibits the lowest depreciation costs as shown in Figure 9, since the high initial purchase cost is outweighed by the superior battery life.
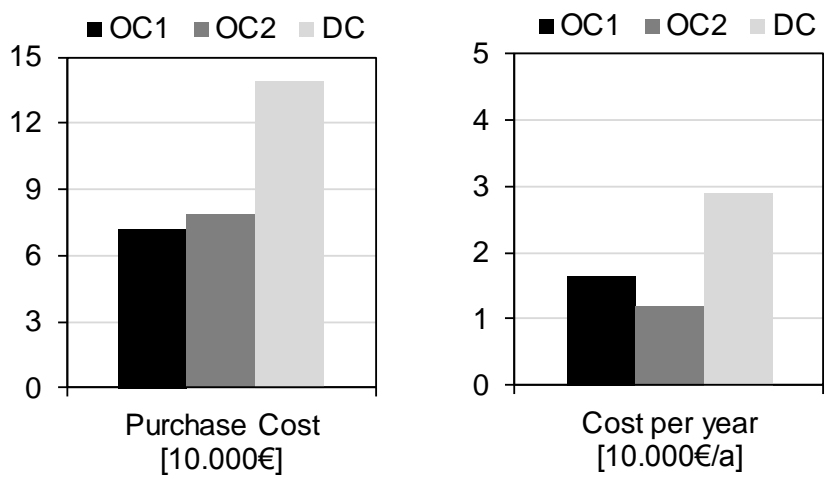

Figure 9: Battery purchase cost (left) and Battery depreciation costs per year (right)

The results illustrate the practical relevance of the proposed methodology for choosing the appropriate technology combination for an electric bus system. However, it should be noted that LTO is relatively a new battery technology and reports on the expected cycle life have to be validated by long term operational results.

\section{CONCLUSION AND FURTHER WORK}

The transformation process from today's diesel to future electric bus systems opens up a vast design space since different charging strategies, several charging technologies and various battery types can be chosen. An exhaustive evaluation of all possible combinations is prohibitive. However, using well established methods of systematic product development and suitable simulation models for vehicle, drive train and battery, a methodology to identify suitable system solutions under given strategic and operational requirements could be developed. The high investment cost and rather limited life-time of batteries compared to all other components in a vehicle is taken into account.

The main focus of this study was the introduction of a feasible methodology. Based on viable technology specifications and reasonable cost data a feasible combination of technologies and design parameters was identified. However, the specific results, are bound to the chosen operational scenario. The battery aging models used here are based on recently published data which should be validated with additional experiments in the near future.

The methodology is applicable to identify most advantageous concepts for electric bus systems but it could be expanded to the electrification of other vehicle fleets like city logistics or other services. Before taking final decisions, however, a detailed analysis of the total cost of ownership (TCO) should be carried out. Such a TCO assessment for the concepts identified in this study has been carried out by Jefferies and Göhlich (2018). In the future, other technologies such as partial trolleybus catenaries and fuel cell powered bus systems could become competitive and should be analysed based on the methodology proposed here. 


\section{REFERENCES}

Aurbach, D. (2000), "Review of selected electrode-solution interactions which determine the performance of Li and Li ion batteries”. In: Journal of Power Sources Vol. 89 No. 2, pp. 206-218.

Bünnagel, C. (2016), “Sileo 18: Ein revolutionäres Konzept”. In: Verkehr und Technik, Bd. Vol. 6, pp. 196-200.

Eudy, L., Prohaska, R., Kelly, K. and Post, M. (2016), "Foothill Transit Battery Electric Bus Demonstration Results”. Technical Report. NREL/TP-5400-65274. Hg. v. National Renewable Energy Laboratory (NREL)

Fay, T.-A. (2019), "Methodischer Technologievergleich von Systemkonzepten für die Elektrifizierung von Stadtbussen". Dissertation. Technische Universität Berlin, Berlin. Methoden der Produktentwicklung und Mechatronik.

Gao, Z., Lin, Z., LaClair, T. J., Liu, C., Li, J.-M., Birky, A. K. and Ward, J. (2017), "Battery capacity and recharging needs for electric buses in city transit service”. In: Energy Vol. 122, pp. 588-600. http://dx.doi.org/10.1016/j.energy.2017.01.101.

Göhlich, D., Fay, T.-A.; Jefferies, D., Lauth, E., Kunith, A, and Zhang, X. (2018), "Design of urban electric bus systems". In: Des. Sci. Vol. 4, S. 0. http://dx.doi.org/10.1017/dsj.2018.10.

Gorbea, C., Hellenbrand, D., Srivastava, T.; Biedermann, W. and Lindemann, U. (2010), "Compatibility matrix methodology applied to the identification of vehicle architectures and design requirements". In: International Design Conference. Design 2010. Dubrovnik, Croatia, May 17 - 20, pp. 733-742.

Hellenbrand, D. and Lindemann, U. (2008): "Using the dsm to support the selection of product concepts". In: 10th International Design Structure Matrix Conference. DSM'08. Stockholm, Sweden, 11-12 November 2008, pp. 363-374

Jefferies, D. and Göhlich, D. (2018), "Integrated TCO Assessment of Bus Network Electrification Considering Rescheduling and Delays”, Modelling Framework and Case Study. In: EVS31 International Electric Vehicle Symposium \& Exhibition. Accepted for publication, Kobe, Japan.

Koebel, C. (2014), "Update Primove Technology and Projects”, VDV Elektrobusse 2014. Verband Deutscher Verkehrsunternehmen (VDV). Berlin, 2014.

Lindemann, U. (2009), Methodische Entwicklung technischer Produkte. Methoden flexibel und situationsgerecht anwenden. 3., korrigierte, Springer-Verlag Berlin Heidelberg (VDI-Buch), Aufl. Berlin, Heidelberg. Online verfügbar unter http://site.ebrary.com/lib/alltitles/docDetail.action?docID=10323208.

Ly, T.-A., Göhlich, D., and Heide, L. (2016), “Assessment of the interaction of charging system and battery technology for the use in urban battery electric bus systems". In: IEEE (Hg.): Vehicle Power and Propulsion Conference. The 13th IEEE Vehicle and Propulsion Conference. Hangzhou, China, 17.20.10.2016. IEEE

Millner, A. (2010), "Modeling Lithium Ion battery degradation in electric vehicles". In: 2010 IEEE Conference on Innovative Technologies for an Efficient and Reliable Electricity Supply. Waltham, MA, pp. 349-356.

Nørregaard, K., Johnsen, B. and Gravesen, C. H. (2016), Battery degradation in electric buses. Danish Technological Institute

Park, S., Zhang, L., and Chakraborty, S. (2017): "Battery assignment and scheduling for drone delivery businesses". In IEEE/ACM International Symposium on Low Power Electronics and Design, July 24-26, 2017.

Rogge, M. and Sauer, D. U. (2013), "Fast charging of battery buses and its impact on the aging of various lithium-ion cell types". In: Intelligente Transport- und Verkehrssysteme und-dienste Niedersachsen e.V. (Hg.): Proceedings of the 10th Hybrid and Electric Vehicles Symposium, Braunschweig, pp. 249-266.

Rogge, M., Wollny, S, and Sauer, D. (2015), "Fast Charging Battery Buses for the Electrification of Urban Public Transport-A Feasibility Study Focusing on Charging Infrastructure and Energy Storage Requirements". In: Energies Vol. 8 No. 5, pp. 4587-4606. http://dx.doi.org/10.3390/en8054587.

Sinhuber, P., Rohlfs, W., and Sauer, D. U. (2012), "Study on Power and Energy Demand for Sizing the Energy Storage Systems for Electrified Local Public Transport Buses”. In: IEEE (Hg.): IEEE Vehicle Power and Propulsion Conference 2012. Seoul, Korea (South)

Spangenberg, F. and Göhlich, D. (2013), “Technology Roadmapping Based on Key Performance Indicators. In: Michael Abramovici und Rainer Stark (Hg.): Smart product engineering. Proceedings of the 23rd CIRP Design Conference, Bochum, Germany, March 11th - 13th, 2013. Berlin: Springer (Lecture Notes in Production Engineering), pp. 377-386 